\title{
Pengelolaan Anestesi untuk Cedera Otak Traumatik pada Pasien dengan Stroke Iskemik
}

\author{
Nency Martaria*), Iwan Abdul Rachman**), MM. Rudi Prihatno $\left.{ }^{* * *}\right)$ \\ ${ }^{*}$ Departemen Anestesiologi \& Terapi Intensif Rumah Sakit Otak Nasional, ${ }^{* *}$ Departemen Anestesiologi \& \\ Terapi Intensif Fakultas Kedokteran Universitas Padjadjaran-RSUP. Dr. Hasan Sadikin Bandung, ${ }^{* * *}$ Departemen \\ Anestesiologi \& Terapi Intensif Fakultas Kedokteran Universitas Jend. Soedirman-RSUD Prof. Dr. Margono \\ Purwokerto
}

\begin{abstract}
Abstrak
Cedera otak traumatik (COT) merupakan salah satu penyebab utama kematian dan disabilitas di seluruh dunia. Kelompok yang paling berisiko mengalami COT adalah pasien geriatrik, dimana mayoritas disebabkan oleh jatuh. Kejadian jatuh salah satunya dikaitkan dengan hemiparesis akibat riwayat stroke. Seorang laki-laki, 68 tahun dengan Glasgow Coma Scale (GCS) M3V1E4. Pasien mengalami cedera kepala akibat jatuh ketika naik tangga. Pasien memiliki riwayat gangguan keseimbangan akibat stroke iskemik dan mendapatkan terapi clopidogrel. Hasil pemeriksaan CT scan memperlihatkan adanya perdarahan akut sub dural dengan penyimpangan garis tengah $0,9 \mathrm{~cm}$. Operasi pertama yang dilakukan adalah kraniektomi dekompresi dan pemasangan kasa untuk kontrol perdarahan. Perdarahan baru ketika operasi, timbul di midparietal kanan dan diduga berasal dari vena penghubung yang dekat dengan sinus. Perdarahan sulit dihentikan dengan total perdarahan $2500 \mathrm{cc}$. Tanda vital selama operasi stabil dengan topangan norepinefrin $0,2 \mathrm{mcg} / \mathrm{kg} / \mathrm{menit}$. Anestesi dengan menggunakan fentanyl $200 \mathrm{mcg}$, propofol $100 \mathrm{mg}$ dan vecuronium berkelanjutan. Pemeliharaan dengan oksigen, compressed air dan sevofluran $2 \%$. Pasien ditransfusi pack red cel (PRC) $700 \mathrm{ml}$. Setelah delapan hari perawatan ICU, kadar fibrinogen dan hemoglobin menjadi normal,dilakukan pengangkatan kassa dari dalam kepala pasien. Saat ini pasien telah dipulangkan dari rumah sakit dengan Glasgow Outcome Scale 3 dan hemiparese sinistra. Pengelolaan anestesi pada operasi pasien memperhatikan kondisi otak akibat COT, stroke iskemik dan efek dari terapi Clopidogrel pada operasi cito. Brain Trauma Foundation memberikan panduan untuk pengelolaan COT yang bertujuan untuk memberikan luaran yang lebih baik.
\end{abstract}

Kata kunci: cedera otak traumatik; stroke iskemik

JNI 2019; 8 (3): 168-179

\section{Anesthetic Management for Traumatic Brain Injury in Patient with Ischemic Stroke}

\begin{abstract}
Traumatic brain injury (TBI) is one of the leading cause of death and disability around the world. Geriatric being the most vulnerable group, mainly because of falling, of which associated with hemiparesis following stroke. A 68 years old man with Glaslow Coma Scale (GCS) M3V1E4 had brain injury after falling from stairs. The patient is having balance disorder following stroke and receiving clopidogrel afterwards. CT-scan showed acute subdural hemorrhage $(\mathrm{SDH})$ with $0.9 \mathrm{~cm}$ midline shift. Decompression craniectomy and gauze insertion to stop the bleeding was done on the first surgery. New onset of bleeding occurred in right midparietal. Bleeding was uncontrollable with total volume of $2500 \mathrm{cc}$. Vital signs remained stable with norepinephrine $0.2 \mathrm{mcg} / \mathrm{kg} / \mathrm{min}$. Anesthesia under fentanyl $200 \mathrm{mcg}$, propofol 100mg, and continuous vecuronium. Patient was transfused with pack red cel (PRC) total of $700 \mathrm{cc}$. After eight days in ICU, fibrinogen and hemoglobin returned to normal level, therefore the patient undergone gauze removal. The patient discharged with GOS 3 and left hemiparesis. Anesthesia management in this patient' surgery focused on brain condition following TBI, ischemic stroke and the effect of clopidogrel therapy in emergency operation. Brain Trauma Foundation issued a management guideline of TBI for better outcome.
\end{abstract}

Key words: traumatic brain injury; ischemic stroke

JNI 2019; 8 (3): 168-179 


\section{Pendahuluan}

Cedera otak traumatik (COT) adalah impaksi ke kepala yang menyebabkan perubahan selular dan makroskopik, yang merupakan salah satu penyebab utama kematian dan disabilitas di seluruh dunia. ${ }^{1-3}$ Kelompok yang paling berisiko mengalami COT adalah pasien usia lanjut, dimana mayoritas COT disebabkan oleh kejadian jatuh. Kejadian jatuh salah satunya dikaitkan dengan hemiparesis akibat riwayat stroke. ${ }^{2,4}$ Lesi yang umum ditemukan pada populasi usia lanjut yaitu lesi fokal, terutama subdural hematoma (SDH), kontusio, dan hematoma intraserebral. Jatuh merupakan penyebab dari 56\% kasus SDH pada populasi geriatri. ${ }^{5}$ Hal ini diduga terkait dengan peningkatan volume rongga subdural akibat atrofi otak pada kelompok pasien geriatri. ${ }^{4}$ Panduan dari brain trauma foundation (BTF) mengatakan indikasi terapi pembedahan untuk SDH akut adalah adanya SDH dengan ketebalan $>10 \mathrm{~mm}$ atau menyebabkan pergeseran midline $>5 \mathrm{~mm}$ tanpa memandang skor GCS, atau SDH dengan ketebalan $<10 \mathrm{~mm}$ atau pergeseran midline $<5 \mathrm{~mm}$ yang disertai penurunan skor GCS 2 poin atau lebih dari saat kejadian cedera hingga admisi, abnormalitas fungsi pupil, atau tekanan intrakranial $(\mathrm{TIK})>20 \mathrm{mmHg}$. Jika ditemukan adanya indikasi, disarankan untuk melakukan tindakan pembedahan sesegera mungkin. ${ }^{5,6}$

Pasien dengan stroke iskemik seringkali mengonsumsi antiplatelet seperti clopidogrel untuk mencegah tromboembolisme. Terdapat beberapa studi yang melaporkan bahwa antiplatelet tidak mempengaruhi mortalitas dan morbiditas pasien COT, namun kebanyakan data yang tersedia menunjukkan bahwa konsumsi antiplatelet sebelum COT meningkatkan risiko luaran yang buruk pada pasien COT. ${ }^{4}$ Keputusan terkait pembedahan dan manajemen anestesi pada pasien COT dengan riwayat stroke iskemik perlu dilakukan secara teliti dan berhati-hati.

\section{Kasus}

\section{Anamnesis}

Pasien datang ke IGD Rumah Sakit pada tanggal 2 Mei 2019 pukul 12.50, pasien datang dengan keluhan jatuh saat naik tangga, tidak ada muntah, tidak ada pusing, tidak ada nyeri kepala dan tidak ada kejang. Tampak benjol di pelipis kiri dengan GCS E4M6V5. Pasien memiliki gangguan keseimbangan dan kelemahan pada sisi kiri sejak enam bulan sebelum masuk rumah sakit. Pasien memiliki riwayat darah tinggi dan mengonsumsi rutin obat darah tinggi. Pasien memiliki riwayat penyakit keluarga darah tinggi dan jantung namun tidak memiliki riwayat alergi. Pasien memiliki riwayat stroke iskemik dan berobat ke rumah sakit pada bulan April 2019 dan mendapatkan terapi clopidogrel. Pada pukul 13.00, pasien mengalami penurunan kesadaran dengan GCS M3V1E4.

\section{Pemeriksaan Fisik}

Keadaan umum compos mentis pada pukul 12.50, GCS E4M6V5, lalu kesadaran menurun menjadi GCS E4M3V1 pada pukul 13.00. Tanda-tanda vital didapatkan tekanan darah 150/90 $\mathrm{mmHg}$, frekuensi nadi $89 \mathrm{x} / \mathrm{m}$, frekuensi pernapasan $20 \mathrm{x} / \mathrm{m}$, saturasi $99 \%$. mata: pupil isokor, diameter $3 \mathrm{~mm} / 3 \mathrm{~mm}$, refleks cahaya $+/+$, pada pukul 13.00 , pupil anisokor, diameter $4 \mathrm{~mm} / 2 \mathrm{~mm}$, refleks cahaya $-/+$, leher: tidak terdapat kaku kuduk, jugular venous pressure (JVP) tidak meningkat, kelenjar getah bening (KGB) tidak membesar, thorax vesikuler $+/+$, ronkhi -/-, wheezing -/-, jantung bunyi jantung I-II normal, murmur -, gallop -, ekstremitas: ektremitas superior dan inferior tidak edema, akral hangat, CRT $<2$ detik. Refleks patologis -, Refleks fisiologis + .

\section{Pemeriksaan Penunjang}

Laboratorium darah lengkap

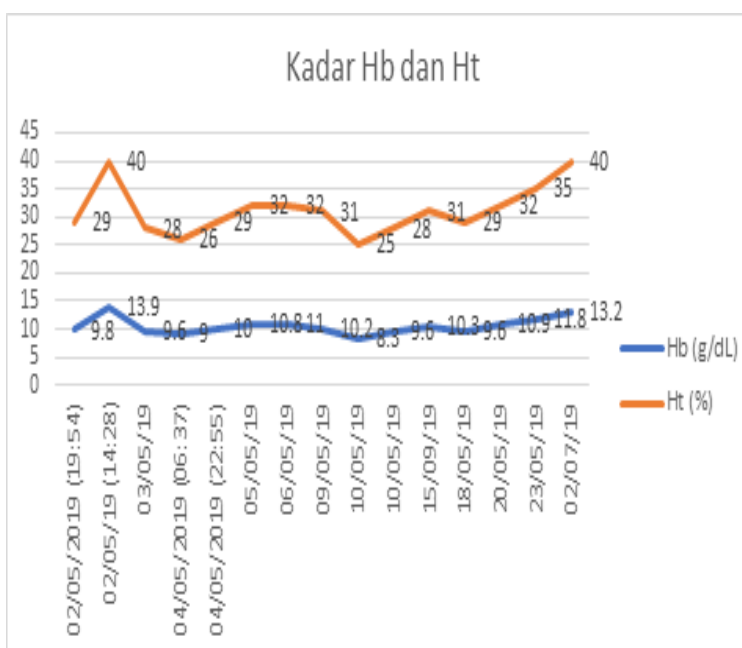


Faktor Koagulasi

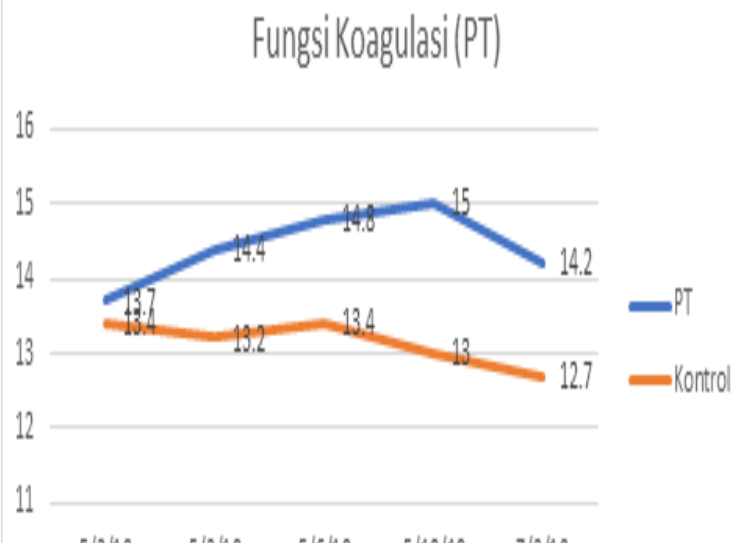

EKG irama sinus tidak ada ST depresi/elevasi, tidak ada $\mathrm{LVH} / \mathrm{RV}$

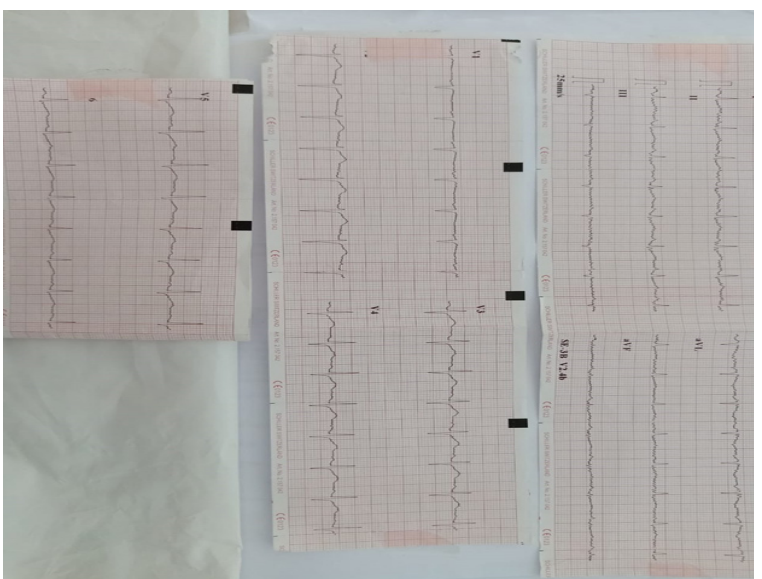

Elektrolit

\begin{tabular}{lllllll}
\hline Elektroli & Satuan & $02 / 05 / 19$ & $09 / 05 / 19$ & $10 / 05 / 19$ & $14 / 05 / 19$ & $23 / 05 / 19$ \\
\hline $\mathrm{Na}$ & $\mathrm{mmol} / \mathrm{L}$ & 138 & 138 & 135 & 138 & 140 \\
$\mathrm{~K}$ & $\mathrm{mmol} / \mathrm{L}$ & 4 & 4,3 & 5,6 & 4,6 & 4,9 \\
$\mathrm{Cl}$ & $\mathrm{mmol} / \mathrm{L}$ & 101 & 104 & 102 & 104 & 101 \\
\hline
\end{tabular}

Kimia Darah

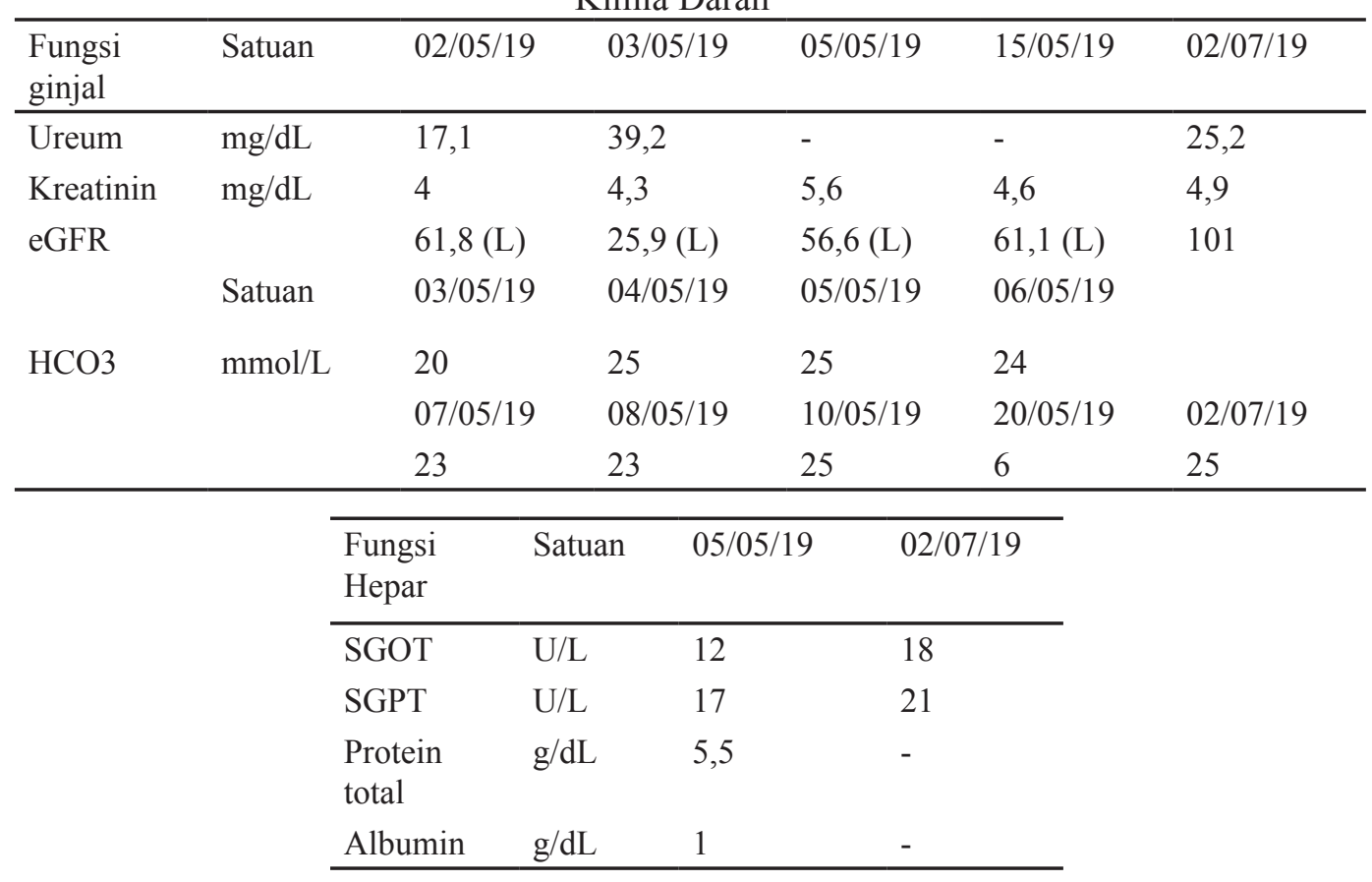

Gula Darah

\begin{tabular}{llllll}
\hline Gula Darah & Satuan & $02 / 09 / 2015$ & $02 / 09 / 2015$ & $10 / 05 / 2019$ & $02 / 07 / 2019$ \\
Glukosa Rapid & $\mathrm{mg} / \mathrm{dL}$ & 195 & 160 & 139 & 114 \\
\hline
\end{tabular}


CT-Scan (2 Mei 2019 preoperasi)

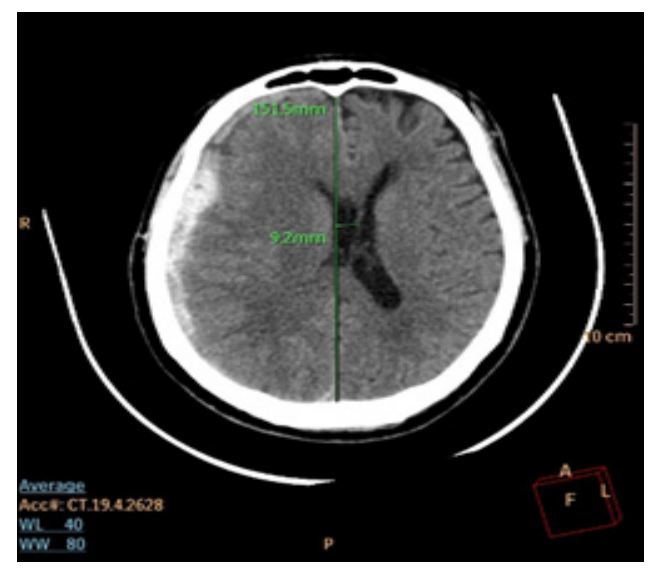

Gambar 1. Hasil pemeriksaan CT-scan 2 Mei 2019.

Hasil CT-Scan (2 Mei 2019, preoperasi): Perdarahan subdural akut di frontotemporoparietal kanan yang menyebabkan pergeseran garis tengah $0,9 \mathrm{~cm}$ ke sisi kiri.

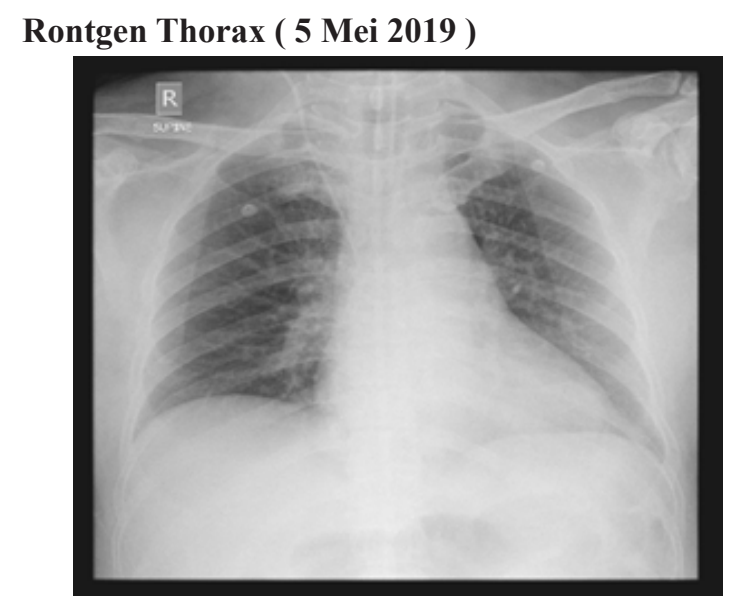

Kesan: terlihat gambaran kardiomegali dan coracan bronkovaskuler meningkat.

Echocardiografi (25 Juli 2018).

Dimensi ruang jantung normal, LVH $(+)$ konsentrik, kontraktilitas global LV baik, EF 68\%, kontraktilitas RV baik, TAPSE $2.5 \mathrm{~cm}$, analisa segmental global normokinetik, katup aorta 3 kuspis, fungsi normal, katup mitral normal, katup trikuspid TR mild (max PG $22 \mathrm{mmHg}$ ), katup pulmonal normal, fungsi diastolik E/A 0,8.

Kesimpulan: fungsi global sistolik LV baik, EF $68 \%$, kontraktilitas RV baik, global normokinetik, TR mild, katup lain normal, low probability of $\mathrm{PH}$.

\section{Pengelolaan Anestesi}

Operasi sito kraniektomi dekompresi dilakukan pada tanggal 2 Mei 2019 dengan anestesi umum dengan pemasangan central venous catheter (CVC), nasogastric tube (NGT), dan juga kateter urine.Anestesi dengan menggunakan fentanyl $200 \mathrm{mcg}$, propofol $100 \mathrm{mg}$ dan vecuronium berkelanjutan. Pemeliharaan dengan oksigen, compressed air dan sevofluran 2\%. Jumlah perdarahan sebanyak $2.500 \mathrm{cc}$ dan dilakukan transfusi darah Packed Red Cell (PRC) sebanyak 700 cc. Tanda vital selama operasi stabil dengan tekanan darah 70-140/40-80 $\mathrm{mmHg}$, nadi $70-100 \mathrm{x} /$ menit dan saturasi $100 \%$ dengan topangan norepinefrin $0,2 \mathrm{mcg} / \mathrm{kg} / \mathrm{menit}$. Hasil pemeriksaan hemoglobin ketika operasi 8,3 g/dL. Setelah operasi, dilakukan perawatan pada pasien di ICU. Di ICU pasien menerima transfusi darah Fresh frozen plasma (FFP) sebanyak $135 \mathrm{cc}$. Pada tanggal 3 Mei 2019, pasien menerima transfusi darah PRC sebanyak 192 cc. Pada tanggal 4 Mei 2019, pasien menerima transfusi darah PRC sebanyak $398 \mathrm{cc}$.

Pada tanggal 10 Mei 2019 dilakukan operasi pengangkatan tamponkasa. GCS sebelum operasi E2M5V afasia. Manajemen anestesi yang digunakan adalah dengan intubasi nafas kendali, menggunakan fentanyl $200 \mathrm{mcg}$, propofol 100 $\mathrm{mg}$ dan vecuronium berkelanjutan. Pemeliharaan dengan oksigen, compressed air dan sevofluran 2\%. Pasien dirawat di High care unit (HCU) pascaoperasi. Pada tanggal 19 Mei 2019 pasien menerima transfusi darah PRC sebanyak 195 cc. Selama perawatan di RS , kadar hemoglobin berkisar 8,3-11,8 g/dL. Hasil pemeriksaan PT/APTT dalam batas normal namun kadar fibrinogen, pada empat hari perawatan, ditemukan tidak normal $(672 \mathrm{mg} / \mathrm{dL})$. Pada tanggal 26 Mei 2019, pasien dipulangkan dari rumah sakit dengan ambulans dengan keadaan GCS E4M5 Vafasia, tekanan darah $140 / 80 \mathrm{mmHg}$, nadi 76 kali/menit. Glasgow Outcome Scale 3 dengan hemiparese sinistra.

\section{Pengelolaan Pascabedah}

Hasil CT-Scan 14 Mei 2019(pasca operasi): Defek tulang post op di frontotemporal kanan dengan herniasi parenkim ringan. Tak tampak 

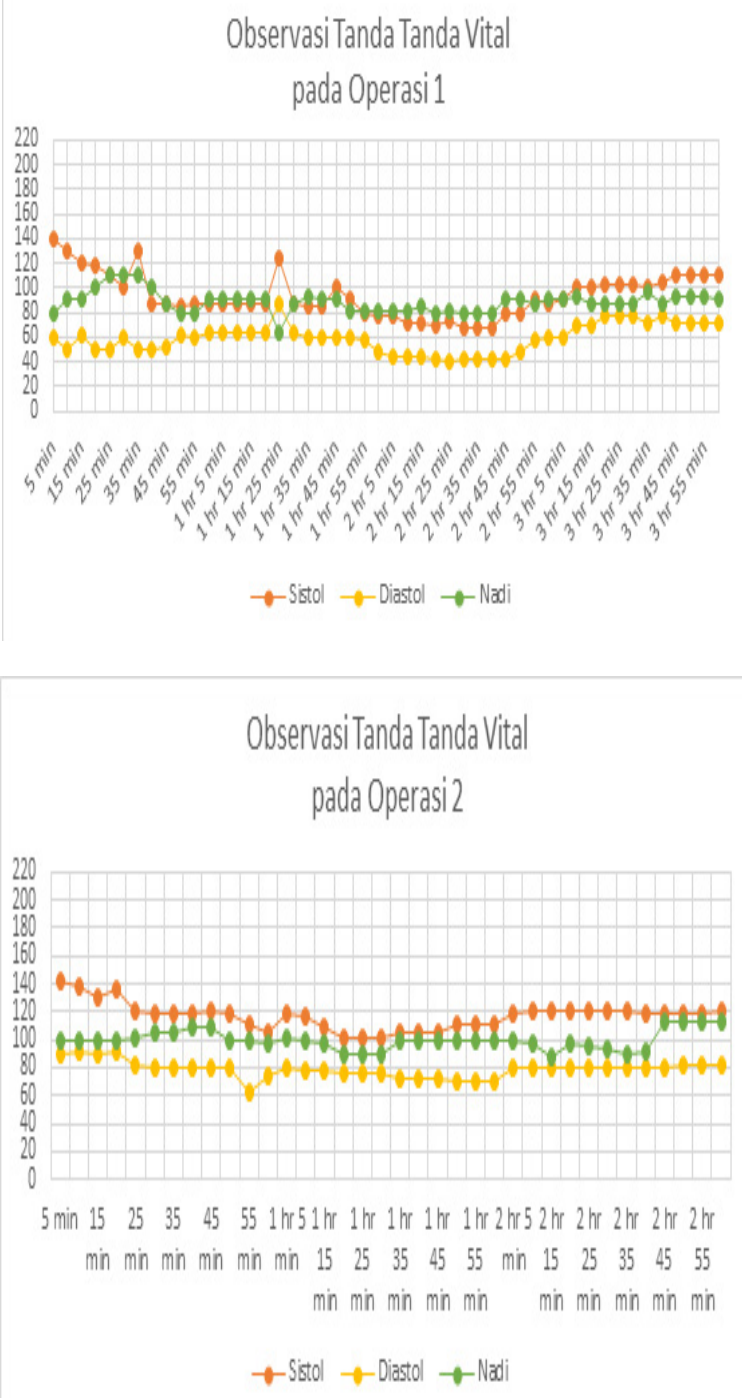

Observasi Tanda-Tanda Vital selama di RS

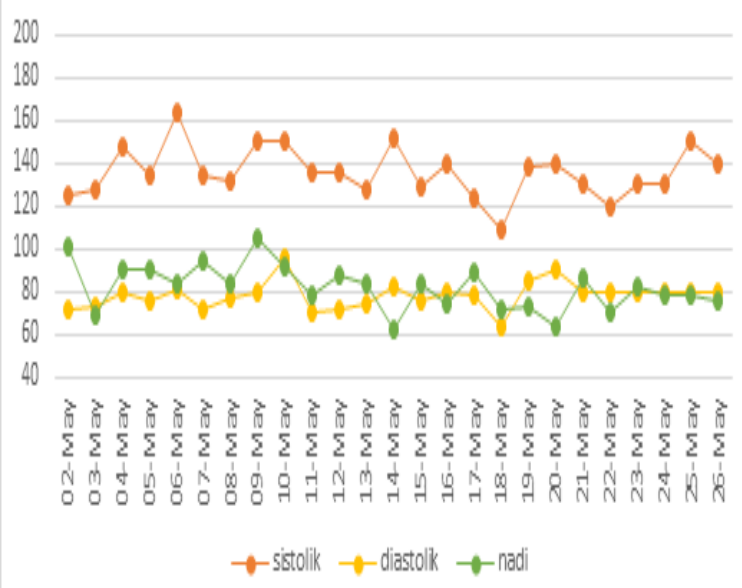

lagi perdarahan subdural. Sulkus dan girus kedua hemisfer baik. Diferensiasi grey dan white matter jelas. Tidak tampak lesi hipodens maupun hiperdens di brain parenkim. Tidak tampak pergeseran garis tengah. Sistem ventrikel dan sisterna baik. Pons, mesensefalon dan serebelum baik. Orbita dan n. optikus kanan kiri baik. Sinus sphenoid kanan kiri tertutup perselubungan. Mastoid kanan kiri baik.

\section{Kesan:}

Defek tulang post op di frontotemporal kanan dengan herniasi parenkim ringan dibandingkan dengan CT sebelumnya. Tak tampak lagi perdarahan subdural. Sinusitis sphenoid bilateral

\section{Pembahasan}

Cedera otak traumatik adalah impaksi ke kepala yang menyebabkan perubahan selular dan makroskopik, yang dapat dideteksi dengan pemeriksaanklinis dandibantudenganpencitraan. ${ }^{1}$ Cedera otak traumatik adalah penyebab utama kematian dan disabilitas di seluruh dunia. Jumlah pasien mengalami kematian akibat COT setiap tahunnya adalah 1,5 juta. Di Amerika Serikat sendiri, setiap 15 detik, terjadi kasus COT baru, sehingga dalam satu tahun didapatkan 1,5 juta kasus baru COT. Lebih dari 250.000 pasien akan menjalani perawatan dari keseluruhan kejadian tersebut, dimana lebih dari 50.000 dari antara pasien tersebut akan mengalami kematian dan 80.000 akan mengalami disabilitas permanen. ${ }^{2,3}$ Data terbaru pada tahun 2013 melaporkan bahwa populasi diatas 75 tahun memiliki insidensi COT tertinggi. ${ }^{7}$ Mayoritas COT disebabkan oleh kejadian jatuh dari kondisi berdiri atau dari ketinggian pada kelompok ini. Kejadian jatuh diasosiasikan dengan penurunan fungsi fisik, termasuk fungsi visual, auditorik, dan keseimbangan. Kejadian jatuh juga dikaitkan dengan penurunan kekuatan otot serta disfungsi kognitif akibat demensia, dan hemiparesis akibat stroke. Beberapa obat-obatan yang dapat menyebabkan atau memperburuk hipotensi ortostatik, seperti vasodilator, antihipertensi, diuretik, penyekat beta, calcium channel blocker, renin-angiotensin system inhibitor, antagonis adrenoreseptor alfa, dan agen dopaminergik 
juga dapat meningkatkan risiko jatuh. ${ }^{4}$ Pasien ini memiliki riwayat gangguan keseimbangan dan kelemahan pada sisi kiri sejak enam bulan sebelum masuk rumah sakit. Pasien juga memiliki riwayat darah tinggi dan mengonsumsi rutin obat darah tinggi, serta riwayat stroke iskemik dan konsumsi rutin clopidogrel. Hal-hal ini merupakan faktor risiko kejadian jatuh yang dialami oleh pasien. Jatuh merupakan salah satu komplikasi utama dari stroke, dimana hingga $37 \%$ penyintas stroke mengalami kejadian jatuh setidaknya $1 \mathrm{x}$ dalam 6 bulan setelah stroke. Hal ini terutama dikaitkan dengan kelemahan motorik yang juga dialami pasien. ${ }^{89}$ Pada pasien pasca stroke juga ditemukan adanya kelainan gait yang dapat meningkatkan risiko jatuh. ${ }^{10,11}$ Konsumsi obat antihipertensi juga meningkatkan risiko jatuh. ${ }^{8}$ Lesi yang umum ditemukan pada populasi usia lanjut yaitu lesi fokal, terutama subdural hematoma (SDH), kontusio, dan hematoma intraserebral. Jatuh merupakan penyebab dari $56 \%$ kasus SDH pada populasi geriatri. ${ }^{5} \mathrm{Hal}$ ini diduga terkait dengan peningkatan volume rongga subdural akibat atrofi otak pada kelompok pasien geriatri, dimana setelah usia 35 tahun, volume otak akan berkurang $0,2-0,5 \%$ per tahun. Hal tersebut mengakibatkan terjadinya peningkatan rongga subdural serta mobilitas hemisfer serebri. Peningkatan risiko SDH juga terkait dengan kerapuhan dinding pembuluh darah karena efek penuaan. Bridging vein menempel ke lapisan duramater atau permukaan otak, sehingga rentan

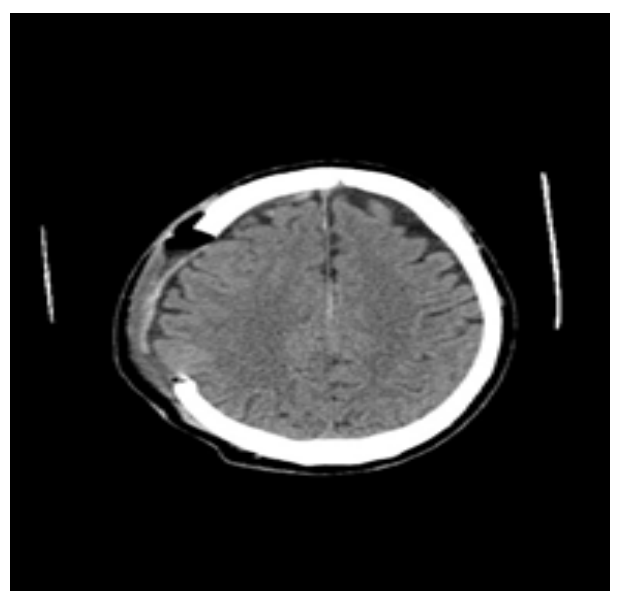

Gambar 3. Hasil pemeriksaan CT-Scan 14 Mei 2019. terjadi kerusakan saat terjadi mobilisasi hemisfer pada trauma yang menimbulkan $\mathrm{SDH} .{ }^{4} \mathrm{Hal}$ ini sesuai dengan lesi yang ditemukan pada pasien yaitu SDH di frontotemporoparietal kanan.

\section{Indikasi dan Waktu Pembedahan}

Indikasi dan waktu yang tepat terkait intervensi bedah pada COT masih kontroversial disebabkan minimnya data terkait pendekatan yang optimal serta luarannya dan keberagaman pola cedera pada COT. Dokter bedah saraf harus mempertimbangkan hasil pemeriksaan radiologi, prognosis, dan keinginan pasien serta keluarga dalam memilih antara terapi pembedahan atau konservatif. Pada tahun 2006, Brain Trauma Foundation (BTF) menerbitkan panduan terkait tata laksana bedah pada COT. Panduan tersebut hanya memuat rekomendasi yang didasarkan pada bukti kelas III karena keterbatasan data. ${ }^{6}$ Subdural hematom ditemukan pada sekitar sepertiga pasien dengan COT berat. Sekitar setengah sampai lebih dari dua pertiga pasien dengan SDH menjalani evakuasi hematoma. Subdural hematom akut diasosiasikan dengan tingkat mortalitas yang tinggi (40-90\%), meskipun berdasarkan studi-studi terbaru, tingkat mortalitasnya sudah menurun hingga $14 \%$.

Panduan dari BTF mengatakan bahwa SDH akut dengan ketebalan $>10 \mathrm{~mm}$ atau menyebabkan pergeseran midline $>5 \mathrm{~mm}$ harus dievakuasi tanpa memandang skor GCS. Pada SDH dengan ketebalan $<10 \mathrm{~mm}$ atau pergeseran midline $<5$ $\mathrm{mm}$, hematoma harus dievakuasi jika ditemukan penurunan skor GCS 2 poin atau lebih dari saat kejadian cedera hingga admisi, abnormalitas fungsi pupil, atau tekanan intrakranial (TIK) > $20 \mathrm{mmHg}$. Pasien dengan SDH akut dan skor GCS $<9$ juga perlu menjalani pemantauan TIK. ${ }^{5,6}$ Waktu dari cedera hingga pembedahan merupakan faktor yang dapat mempengaruhi morbiditas dan mortalitas, namun hingga saat ini, belum terdapat standar terkait hal ini. BTF merekomendasikan pada pasien SDH dengan indikasi pembedahan, pembedahan harus dilakukan sesegera mungkin. ${ }^{5}$ Kraniotomi dalam 4 jam setelah terjadinya epidural hematoma $(\mathrm{EDH})$ atau SDH juga digunakan sebagai indikator kualitas oleh the American College of Surgeons Committee on 


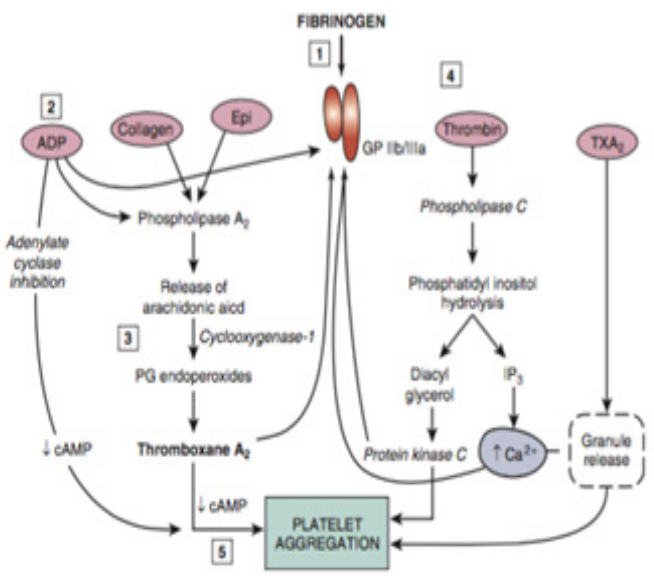

Gambar 1. Peran jaras ADP yang Diinhibisi oleh Klopidogrel dalam Agregasi Platelet ${ }^{13}$

Trauma.Hasil studi-studi terbaru menunjukkan bahwa waktu dari penurunan neurologis (awitan koma atau disfungsi batang otak) hingga pembedahan diduga lebih mempengaruhi luaran daripada waktu antara cedera dan pembedahan, maka dari itu pasien COT dengan gangguan neurologis signifikan akibat lesi masa intrakranial harus menjalani pembedahan sesegera mungkin untuk memaksimalkan pemulihan. ${ }^{6}$

Pasien ini mengalami SDH pasien yaitu di frontotemporoparietal kanan yang menyebabkan pergeseran garis tengah $9 \mathrm{~mm}$ ke sisi kiri, sehingga memenuhi indikasi untuk dilakukannya evakuasi pembedahan. Sesuai rekomendasi dari $\mathrm{BTF}$, prosedur ini harus dilakukan sito/sesegera mungkin. Keputusan pemilihan prosedur antara kraniotomi atau kraniektomi didasarkan pada hasil radiografi preoperatif, penilaian edema serebri intraoperatif, dan preferensi ahli bedah. Belum ada cukup bukti yang menunjukkan superioritas salah satu prosedur, namunsebuah studi menunjukkan peningkatan standardized morbidity ratio pada pasien yang ditatalaksana dengan kraniektomi, sehingga prosedur ini dapat menjadi pilihan pada pasien-pasien dengan $\mathrm{SDH}$, termasuk pada pasien ini. ${ }^{6}$

\section{Pengaruh Konsumsi Antiplatelet pada COT}

Antiplatelet seperti aspirin, cilostazol, dan klopidogrel umum digunakan untuk mencegah tromboembolisme pada pasien dengan stroke iskemik. Terdapat beberapa studi yang melaporkan bahwa antiplatelet tidak mempengaruhi mortalitas dan morbiditas pasien COT, meskipun begitu kebanyakan data yang tersedia menunjukkan bahwa konsumsi antiplatelet sebelum COT meningkatkan risiko luaran yang buruk pada pasien COT, terutama akibat hematoma intrakranial yang lebih besar atau berulang. Pasien yang memiliki riwayat konsumsi antiplatelet, perlu dipertimbangkan penghentian dan/atau reversal obat tersebut setelah COT, terutama pada pasien dengan hematoma intrakranial. Pertimbangan ini harus didasarkan pada risiko tromboembolisme masing-masing pasien serta ekstensi hematoma intrakranial. ${ }^{4,12}$

Klopidogrel merupakan antagonis reseptor ADP (P2Y12) dari trombosit yang memerlukan waktu 5 hari sampai efeknya hilang setelah penghentian terapi. Peran reseptor ADP dalam agregasi platelet dapat dilihat pada gambar 1. Agen reversal potensial yang dapat digunakan untuk klopidogrel mencakup trombosit, desmopresin, dan rFVIIa. ${ }^{4}$ Klopidogrel merupakan salah satu obat yang dikonsumsi pasca stroke. Guideline stroke iskemik AHA menyarankan pasien pasca stroke untuk mengkonsumsi double antiplatelet (DAPT) yang terdiri dari klopidogrel dan aspirin dalam waktu 24 jam pasca serangan dan dilanjutkan hingga 21 hari. Selanjutnya pasien hanya mengkonsumsi klopidogrel $75 \mathrm{mg} /$ hari untuk pencegahan sekunder stroke iskemik. ${ }^{14}$

Konsumsi klopidogrel diperkirakan menjadi penyebab terjadinya perdarahan intraoperatif yang tidak dapat dihentikan, selain kemungkinan adanya pengaruh dari koagulopati akibat COT. Semua pasien COT seharusnya menjalani pemeriksaan laboratorium terkait parameter koagulasi (jumlah trombosit, bleeding time, PT, PTT, INR, atau tromboelastografi). ${ }^{1,15}$ Klopidogrel sendiri diasosiasikan dengan risiko perdarahan intraoperatif yang lebih tinggi daripada aspirin. ${ }^{16}$ Kasus ini menunjukan hasil pemeriksaan PT dan PTT sebelum operasi normal. PT dan APTT tidak mencerminkan keseluruhan status koagulasi pasien, klopidogrel yang dikonsumsi pasien merupakan antiplatelet yang bekerja dengan cara 
menginhibisi trombosit sehingga kemungkinan tidak mempengaruhi PT dan PTT melainkan bleeding time. Pasien seharusnya menerima terapi reversal untuk menormalkan efek dari klopidogrel karena tidak mungkin dilakukan penghentian klopidogrel dan penundaan pembedahan selama 5 hari untuk menunggu hilangnya efek klopidogrel. Pendekatan lain yang mungkin digunakan adalah pemberian transfusi trombosit, namun metode ini masih memerlukan studi lebih lanjut. ${ }^{13,17}$

\section{Manajemen Anestesi pada Pasien dengan COT dan Riwayat Stroke Iskemik}

Kerjasama dan komunikasi antara ahli bedah dan tim anestesi sangat penting dalam operasi neurotrauma. Adanya kondisi politrauma, risiko perdarahan masif dan cepat, serta koagulopati menuntut pengawasan yang ketat dan intervensi segera. ${ }^{6}$ Terlebih,padapasiendenganriwayatstroke iskemik terdapat peningkatan risiko perioperatif terkait disabilitas neurologis, komorbiditas, dan efek anestesi serta pembedahan. ${ }^{16}$ Pasien dengan riwayat stroke iskemik dapat mengalami stroke perioperatif, yaitu infark iskemik atau hemoragik yang terjadi selama pembedahan atau dalam 30 hari pasca pembedahan. Hal ini terkait gangguan cardiac output, metabolisme serebral, dan oksigenasi yang dicetuskan oleh anestesi dan pembedahan. Kondisi hiperkoagulabilitas akibat trauma pembedahan dan imobilisasi pasca operasi serta penghentian antiplatelet juga meningkatkan risiko stroke iskemik pasca operasi. Kejadian stroke perioperatif dapat meningkatkan mortalitas hingga $8 \mathrm{x}$ dengan mortalitas hingga $60 \%$ pada pasien dengan riwayat stroke sebelumnya. Pada pasien dengan riwayat stroke iskemik juga dapat terjadi peruburukan kondisi hemiplegia atau defisit neurologis lainnya yang awalnya sudah mengalami perbaikan pasca pajanan terhadap benzodiazepin, opioid, atau anestesi umum. Fenomena ini bersifat sementara dan umumnya pulih dalam waktu singkat. Penurunan perfusi serebral akibat obat pada area penumbra diduga menyebabkan defisit ini. Pasien dengan imobilitas lama akibat stroke memiliki peningkatan risiko aspirasi akibat gangguan menelan, batuk yang tidak efektif, penurunan pengosongan lambung, deep venous thrombosis, dan pulmonary embolism. Pasien-pasien dengan riwayat stroke iskemikseringkali memiliki asupan nutrisi yang buruk sehingga meningkatkan risiko gangguan elektrolit, hipoproteinemia, dan peningkatan sensitivitas terhadap agen anestesi. Adanya komorbiditas berupa penyakit jantung, ginjal, hipertensi, diabetes, dan penyakit paru obstruktif kronis juga perlu menjadi perhatian. ${ }^{16}$

Terdapat beberapa pemeriksaan dan optimalisasi kondisi yang perlu dilakukan sebelum dilakukan anestesia. Hal terpenting adalah mengidentifikasi faktor risiko yang dapat memperburuk luaran pasien pasca pemberian anestesi. Perlu dilakukan pemeriksaan terhadap status serebrovaskular dan morbiditas perioperatif lainnya. Status serebrovaskuler dapat dilihat dengan melakukan pemeriksaan defisit neurologis secara lengkap, pemeriksaan penunjang yang dapat dilakukan antara lain adalah doppler karotis atau magnetic resonance angiography, terutama jika riwayat kejadian stroke baru terjadi. Seluruh sistem organ mayor juga perlu dievaluasi untuk mengidentifikasi adanya kelainan, terutama penyakit jantung iskemik, riwayat infark sebelumyna, disfungsi sistolik, ataupun disfungsi atrium yang terjadi pada pasien perlu ditangani sebelum dilakukan operasi. Penyakit penting lainnya untuk diperiksa adalah diabetes, hipertensi, gangguan ginjal kronik, PPOK, thrombosis vena dalam, dan penyakit infeksi (seperti pneumonia). Penapisan penyakit-penyakit tersebut dapat dilakukan dengan pemeriksaan penunjang yang dilakukan sebelum operasi antara lain darah perifer lengkap, kimia darah, enzim jantung, faal koagulasi, dan echocardiography. Pasien ini tidak dilakukan pemeriksaan enzim jantung karena kondisi operasi yang sito, sehingga kelainan jantung hanya ditapis melalui pemeriksaan EKG, dan pasien tidak menunjukan adanya kelainan pada EKG. ${ }^{15}$ Pasien COT memerlukanarterial line dan akses intravena yang cukup disamping pemantauan dasar. ${ }^{18}$ Pasien dengan riwayat stroke iskemik juga memerlukan beberapa pemantauan tambahan seperti pemantauan tekanan darah invasif, central venous pressure, dan urine output. Pemantauan neuromuscular junction juga dapat dilakukan pada sisi yang tidak terkena stroke. Durasi operasi juga perlu diminimalisasi 
untuk menurunkan risiko komplikasi dan stroke perioperatif. ${ }^{16}$ Pemeliharaan anesthesia dapat menggunakan anestesi intravena ataupun inhalasi. Literatur terbaru menunjukan bahwa tidak ada perbedaan luaran antara penggunaan anestesi intravena dan inhalasi ataupun kombinasi keduanya. Tim anestesi harus memperhatikan panduan klinis dari BTF yaitu mencegah hipoksemia, $\mathrm{PaO}_{2}<60 \mathrm{mmHg}$, saturasi oksigen $<90 \%$, hiperkarbia, hipotensi, dan tekanan darah sistolik $<90$ mmHg. ${ }^{18}$

Hipotensi dan hipoksia harus dihindari selama pembedahan pasien COT untuk mencegah kerusakan otak sekunder. ${ }^{6}$ Berdasarkan rekomendasi dari BTF, tekanan darah sistolik harus dipertahankan $>90 \mathrm{mmHg}$ dan CPP 50 $70 \mathrm{mmHg}$ untuk mencegah iskemia otak lebih lanjut. ${ }^{18}$ Hal ini terutama penting dilakukan pada pasien dengan riwayat stroke iskemik yang dapat mengalami dampak buruk dari penurunan perfusi serebri. Pada populasi pasien ini, tekanan darah selama operasi harus dipertahankan minimal sesuai tekanan darah sebelum operasi. ${ }^{16}$ Pasien dengan hipertensi intrakranial dapat mengalami hipertensi arterial sebagai respons sistemik terhadap penurunan tekanan perfusi serebral. Respons Cushing ini bertujuan mengembalikan perfusi serebral untuk mencegah iskemia lebih lanjut. Penurunan TIK yang cepat dan normalisasi tekanan perfusi serebral dapat menyebabkan hilangnya pemicu hipertensi sistemik secara mendadak sehingga pasien dapat mengalami kolaps sirkulasi selama pembedahan dekompresi. Tim anestesi harus siap untuk menghadapi kemungkinan kejadian ini dan ahli bedah harus menginformasikan kepada tim anestesi sebelum melakukan dekompresi. ${ }^{6}$ Manajemen hipotensi dapat dilakukan dengan vasopresor. Tata laksana hipertensi dilakukan dengan memilih agen yang dapat dititrasi dengan mudah dan tidak menyebabkan vasodilatasi sebreal untuk mencegah peningkatan TIK. Agen yang umum digunakan mencakup propanolol, esmolol, labetolol, dan nikardipin. ${ }^{18}$

Pasien dengan riwayat stroke iskemik yang mengalami hipoksia intraoperatif dan edema serebri juga dapat mengalami perfusi ke daerah penumbra yang meningkatkan kerusakan iskemik sehingga harus dilakukan pengawasan ketat pada tekanan parsial $\mathrm{CO}_{2} \cdot{ }^{16}$ Hiperkarbiapada pasien COT terkait administrasi agen hipnotik atau sedatif seperti benzodiazepin, narkotik, dll sebelum induksi anestesi harus dihindari. ${ }^{18}$ Premedikasi sedasi juga sebaiknya dihindari atau diberikan dalam dosis minimal pada pasien dengan riwayat stroke iskemik karena risiko sensitivitas yang tinggi. Selain itu, pada pasien COT dengan riwayat stroke iskemik, hiperventilasi juga harus dihindari karena dapat menyebabkan hipokarbia yang menurunkan aliran darah serebral. Hiperventilasi juga dapat menurunkan aliran darah cerebral dan tekanan intrakranial, hiperventilasi hanya dilakukan sementara untuk mencegah terjadinya herniasai. ${ }^{16}$

Adanya kemungkinan koagulopati pada COT menyebabkan perlunya pemeriksaan parameter koagulasi segera pada pasien COT dan abnormalitas harus segera ditatalaksana. INR harus dipertahankan 1,4 atau kurang dan trombosit $>75.000 /$ mikroliter. Hemoglobin harus dipertahankan $7 \mathrm{~g} / \mathrm{dL}$ atau lebih untuk mencegah penurunan oksigenasi otak. Tidak ada bukti menguntungkan terkait transfusi agresif hingga $\mathrm{Hb} 10 \mathrm{~g} / \mathrm{dL}$. Transfusi dapat dipertimbangkan jika $\mathrm{Hb}$ turun $<7 \mathrm{~g} / \mathrm{dL} .{ }^{18}$ Hiperglikemia dapat menyebabkan peningkatan metabolisme dan kematian neuronal. Pada pasien dengan riwayat stroke iskemik, hipoglikemia juga harus dihindari karena otak sangat tergantung pada suplai glukosa. Kadar gula darah harus dipertahankan pada rentang 60-180 mg/dL. ${ }^{16,18}$ Rekomendasi dari BTF terkait suhu menyarankan untuk mempertahankan kondisi normotermia. ${ }^{18}$ Demikian pula untuk pasien dengan riwayat stroke iskemik, disarankan untuk mempertahankan suhu normal. ${ }^{16}$ Temperatur sentral juga harus selalu dipantau pada pasien COT terkait risiko hipotermia akibat trauma dan anestesia. ${ }^{15}$

Pasien dengan riwayat stroke iskemik harus diberikan profilaksis anti-aspirasi terkait kemungkinan gangguan pengosongan lambung dan refleks protektif saluran napas. Perlu juga dilakukan pencegahan inflamasi dan infeksi. Penggunaan kortikosteroid tidak diindikasikan. Kelompok pasien iniharus dinilai kepulihan dari 
refleks protektif jalan napas sebelum dilakukan ekstubasi. Diupayakan kesadaran segera dari pasien pasca operasi untuk penilaian neurologis postoperatif. Fenomena "differential awakening" dapat ditemukan, dimana fungsi motorik pada sisi yang terkena stroke kembali sedikit lebih lambat. Jika didapatkan adanya defisit motorik baru, pasien harus dipantau dan dapat dilakukan pemeriksaan radiologis. ${ }^{16}$

Pemberian cairan yang disarankan adalah normal salin, dan pemberian cairan hipotonik perlu dihindari karena dapat meningkatkan tekanan intrakranial dengan cara meningkatkan edema otak. Hindari pemberian cairan dengan glukosa tinggi karena glukosa akan di metabolisme sehingga hanya tersisa air dan menjadi larutan yang hipotonik. Ringer laktat juga tidak disarankan karena bersifat sedikit hipotonik. ${ }^{5}$

\section{Pemilihan Obat Anestesi pada Pasien COT dengan Riwayat Stroke Iskemik}

Pasien dengan riwayat stroke iskemik tidak umum diberikan dosis agen anestesi yang tinggi untuk tujuan proteksi serebral karena potensi fluktuasi hemodinamik. ${ }^{16}$ Agen anestesi intravena yang menurunkan metabolisme serebral menghasilkan efek protektif bagi otak pada pasien COT dengan riwayat stroke iskemik. Agen inhalasi juga memiliki efek vasodilatasi sehingga dapat menguntungkan. Penambahan opioid kerja singkat atau menengah dapat menekan refleks saluran napas, menurunkan dosis agen induksi sehingga menurunkan instabilitas hemodinamik selama induksi, dan juga menurunkan dosis anestesi inhalasi pemeliharaan yang diperlukan. Penggunaannya juga dapat membantu menumpulkan respons simpatis terhadap laringoskopi direk. Data terkait agen spesifik yang lebih bersifat neuroprotektif belum tersedia. Fentanil, sufentanil, dan remifentanil sering digunakan pada pasien COT. Opioid harus dititrasi secara berhati-hati untuk mencegah hipotensi. ${ }^{16,18}$

Propofol menurunkan aliran darah serebral, konsumsi oksigen serebral, dan TIK, serta tidak mempengaruhi autoregulasi serebral, oleh karena itu, agen ini dapat dipertimbangkan sebagai pilihan agen anestesi pada pasien COT pada umumnya. ${ }^{16}$ Propofol juga memiliki kelebihan berupa onset dan offset yang cepat sehingga memungkinkan penilaian neurologis. Propofol juga dapat menurunkan stress oksidatif neuronal. Perlu diperhatikan efek blokade simpatis dari propofol yang dapat menimbulkan hipotensi yang ditoleransi secara buruk oleh pasien COT. Agen anestesi volatil seperti halothane, isofluran, dan sevofluran memiliki efek vasodilatasi serebri yang bersifat dose-dependent. Sevofluran menghasilkan efek vasoaktif yang paling rendah serta memiliki kemampuan menurunkan tingkat metabolisme oksigen otak yang sebanding dengan propofol, oleh karena itudari semua agen volatil, sevofluran merupakan agen yang paling cocok untuk neuroanestesia. Nitrit oksida meningkatkan aliran darah serebral akibat stimulasi serebri dan peningkatan laju metabolik serebri; agen ini juga menyebabkan takipnea, takikardia, dan peningkatan tekanan darah sistemik. Agen ini sebaiknya tidak digunakan pada pasien COT berat dengan peningkatan TIK. 6Penggunaannya nitrit oksida tidak terbukti meningkatkan risiko stroke pada pasien COT dengan riwayat stroke iskemik. $^{16}$

Agen neuromuscular blocker yang bersifat cardio-stable dan non-depolarizing dapat digunakan, jika hemodinamik yang stabil berhasil dicapai pada pasien COT dengan riwayat stroke, maka maintenance anestesi dengan agen inhalasi atau propofol dapat dilakukan. ${ }^{16}$ Pasien ini menjalani kraniektomi sito dibawah anestesi umum dengan menggunakan fentanil $200 \mathrm{mcg}$, propofol $100 \mathrm{mg}$ dan vecuronium berkelanjutan. Pemilihan propofol sudah sesuai dengan rekomendasi yang ada untuk pasien COT dengan riwayat stroke iskemik. ${ }^{16,18}$ Penambahan fentanil yang merupakan opioid juga dapat memberikan dampak positif berupa penekanan refleks saluran napas serta penurunan kebutuhan dosis agen induksi dan anestesi inhalasi pemeliharaan. Fentanil juga dapat membantu menumpulkan respons simpatis terhadap laringoskopi direk. ${ }^{16,18}$

Suksinilkolin harus dihindari pada pasien dengan riwayat stroke karena kemungkinan terjadinya hiperkalemia yang bersifat fatal, penggunaan 
vecuronium yang merupakan non-depolarizing neuromuscular blocker ${ }^{19}$ sudah tepat pada pasien ini. Pemeliharaan anestesia pada pasien ini dilakukan dengan oksigen, compressed air dan sevofluran 2\%. Sevofluran menghasilkan efek vasoaktif yang paling rendah serta memiliki kemampuan menurunkan tingkat metabolisme oksigen otak yang sebanding dengan propofol sehingga merupakan pilihan yang paling cocok untuk neuroanestesia dibandingkan agen anestesi volatil lainnya. ${ }^{6}$ Tekanan darah pasien selama operasi berada pada rentang 70-140/40-80 $\mathrm{mmHg}$, sesuai dengan rekomendasi dari BTF, dimana tekanan darah sistolik harus dipertahankan diatas $90 \mathrm{mmHg}$. 18Mengingat adanya riwayat stroke iskemik pada pasien, tekanan darah pasien dapat dipertahankan pada rentang yang lebih tinggi, minimal sesuai tekanan darah sebelum operasi (150/90 mmHg). ${ }^{16}$ Penggunaan topangan vasopresor berupa norepinefrin $0,2 \mathrm{mcg} / \mathrm{kg} /$ menit sudah sesuai dengan rekomendasi untuk pencegahan hipotensi pada pasien COT. ${ }^{18}$

Kadar hemoglobin pasien ketika operasi adalah $8,3 \mathrm{~g} / \mathrm{dL}$. Pasien menerima transfusi darah PRC sebanyak 700 cc selama operasi, 192cc 1 hari pasca operasi, dan 398cc 2 hari pasca operasi. Pemberian transfusi ini sebenarnya tidak diperlukan berdasarkan panduan terkini yang menyatakan bahwa meksipun penting untuk mempertahankan kadar hemoglobin untuk mencegah penurunan oksigenasi otak, tidak ada keuntungan dari transfusi agresif sehingga transfusi dapat dipertimbangkan jika $\mathrm{Hb}$ turun $<7 \mathrm{~g} / \mathrm{dL} .{ }^{18,20}$ Pasien juga menerima transfusi fresh frozen plasma (FFP) sebanyak 135 cc selama perawatan pascaoperasi di ICU. Pasien dengan COT biasanya diberikan transfusi FFP untuk memperbaiki koagulopati. Studi terkait hal ini masih sangat terbatas. Kebanyakan studi yang ada memiliki desain retrospektif dengan jumlah sampel yang minimal, sehingga pemberian transfusi FFP tidak rutin dianjurkan terutama pada pasien dengan koagulopati ringan-sedang. ${ }^{20}$

\section{Simpulan}

Cedera otak traumatik pada pasien geriatrik sering diakibatkan gejala kelemahan tungkai akibat stroke iskemik. Pengelolaan anestesi pada operasi pasien memperhatikan kondisi otak akibat COT, stroke iskemik dan efek dari terapi klopidogrel pada operasi cito. Brain Trauma Foundation memberikan panduan untuk pengelolaan COT yang bertujuan untuk memberikan luaran yang lebih baik.

\section{Daftar Pustaka}

1. Mirza FA, Fraser JF. Traumatic brain injury. Dalam: Ferri FF, editor. Ferri's Clinical Advisor 2019. USA: Elsevier; 2019, 13391402 .

2. Aisiku IP, Silvestri DM, Robertson CS. Critical care management of traumatic brain injury. Dalam: Winn HR, editor. Youmans and Winn Neurological Surgery. 7th ed. USA: Elsevier Inc.; 2017, 2876-97.

3. Carlile MC, Yablon SA, Mysiw WJ, Frol $A B$, Lo D, Diaz-Arrastia R. Deep venous thrombosis management following traumatic brain injury: A practice survey of the traumatic brain injury model systems. J Head Trauma Rehabil. 2006;21(6):483-90.

4. Karibe H, Hayashi T, Narisawa A, Kameyama M, Nakagawa A, Tominaga T. Clinical characteristics and outcome in elderly patients with traumatic brain injury: For establishmentofmanagement strategy. Neurol Med Chir (Tokyo). 2017;57(8):418-25.

5. Bullock MR, Chesnut R, Ghajar J, Gordon D, Hartl R, Newell DW, et al. Guidelines for the surgical management of TBI. Vol. 58, Neurosurgery. 2006, 58; S2-1-S2-62.

6. Huang MC. 351 Surgical management of traumatic brain unjury. Seventh Ed. Youmans and Winn Neurological Surgery, 4-Volume Set. Elsevier Inc.; 2019, 2910-21.

7. Peters ME, Gardner RC. Traumatic brain injury in older adults: do we need a different 
approach? Concussion. 2018;3(3):CNC56.

8. Tan K, Tan M. Stroke and falls-Clash of the two titans in geriatrics. Geriatrics. 2016;1(4):31.

9. Cho K, Yu J, Rhee H. Risk factors related to falling in stroke patients: a cross-sectional study. J Phys Ther Sci. 2015;27(6):1751-3.

10. Balaban B, Tok F. Gait disturbances in patients with stroke. PM R. 2014;6(7):635-42.

11. Li S, Francisco GE, Zhou P. Post-stroke hemiplegic gait: New perspective and insights. Front Physiol. 2018;9 (AUG):1-8.

12. Bhattacharya B, Maung AA. Anesthesia for patients with traumatic brain injuries. Anesthesiol Clin. 2016;34(4):747-59.

13. Weksler BB. Antiplatelet therapy for secondary prevention of stroke. Sixth Edit. Stroke: Pathophysiology, Diagnosis, and Management. 2004, 1107-28.

14. Kernan WN, Ovbiagele B, Black HR, Bravata DM, Chimowitz MI, Ezekowitz MD, et al. Guidelines for the prevention of stroke in patients with stroke and transient ischemic attack: A guideline for healthcare professionals from the American Heart
Association/American Stroke Association. Stroke. 2014; 45: 2160-260.

15. Mejia MJH, Gonzalez ALF. Anesthesia for patients with traumatic brain injury. Colomb J Anesthesiol. 2014;43(x x):3-8.

16. Karnik H, Jain R. Anesthesia for patients with prior stroke. J Neuroanaesth Crit Care. 2018;05(03):150-7.

17. Li C, Hirsh J, Xie C, Johnston MA, Eikelboom JW. Reversal of the anti-platelet effects of aspirin and clopidogrel. J Thromb Haemost. 2012;10(4):521-8.

18. Qureshi H, Mithaiwala H, Ezell J, Maurtua $M$. Anesthetic management of traumatic brain injury. Clin Med Rev Case Rep. 2017;4(159).

19. Miller RD. Neuromuscular blocking drugs. Dalam: Pardo MC, Miller RD, editors. Basics of Anesthesia. 7th ed. Elsevier Inc.; 2018, 156-75.

20. Stolla M, Zhang F, Meyer MR, Zhang J, Dong JF. Current state of transfusion in traumatic brain injury and associated coagulopathy. Transfusion. 2019;59(S2):1522-8. 